\title{
The Art of Advocacy: Renaissance of Rhetoric in the Law School
}

\section{Professor Gary Watt, Warwick Law School*}

In his book The Art of Persuasion: Tradition and Technique, Adrian Whitfield QC observes that in 'In some universities, law courses include an introduction to classical rhetoric as a training aid. Yet in Britain young lawyers are not routinely introduced to its principles, and so far as I am aware there is no structured approach to teaching them the art of persuasion as such, that is to say to addressing the question basic to all advocacy, namely "what actually persuades other people?". ${ }^{1}$ This paper offers some ruminations on the place of rhetoric in modern legal education and some reflections on the undergraduate module The Art of Advocacy: Mooting and Forensic Rhetoric which I devised and taught for the first time in 2016. ${ }^{2}$ That module does not offer law students a 'routine introduction' or even an especially

\footnotetext{
* I am grateful to my students in the first cohort of the module The Art of Advocacy for choosing to take the untested module and for making more of it than I could have hoped, and to Sean Mulcahy, a joint PhD candidate at the School of Law, Warwick University and the Centre for Theatre and Performance, Monash University, for his typically thoughtful observations on an earlier draft.

${ }^{1}$ Published by The Honourable Society of the Middle Temple (2015).

${ }^{2}$ Similar courses have a long history in the United States, where there has traditionally been great respect for the Classical origins of the nation's rhetorical mode of legal and political debate. Professor Michael Frost, who teaches a course on 'Law \& Rhetoric' at Southwestern Law School, Los Angeles, is the author of the excellent Introduction to Classical Legal
} Rhetoric: A Lost Heritage (Aldershot, Ashgate 2005). The reader is also directed to Linda L. 
'structured approach', but it does seek to engage law students in that perennial (and, in the legal and political context of 2016, acutely topical) question 'what actually persuades other people?' This question demands a radical response that digs down to the shared rhetorical root from which trial advocacy, political speeches and theatrical drama have all sprung. The Art of Advocacy module aims to develop law students' persuasive and ethical practices with reference to the insights of classical rhetoricians and their early modern counterparts. I am using 'ethical' in this context to refer to something that goes beyond the speaker's ethos as a feature of their persuasive appeal to include concern for the social outcomes to which the speaker is seeking to move their audience.

The idea of proposing the new module was prompted by a number of considerations. First, the hope that it might urge students towards a more liberal appreciation of law's historical relation to the humanities, especially the arts of rhetoric, thereby equipping them with attitudes and skills that will not only make them better lawyers but also enhance their prospects for whatever their career plan (or lack of one) might be. Related to this was the hope that a dedicated module would enable deeper engagement with ethical aspects of advocacy of the sort that the constraints of extra-curricular student mooting do not readily admit. In his paper 'Vico, Llewellyn and the Task of Legal Education', Francis J. Mootz III

Berger's generous extended reflections on an upper-level elective course in Law \& Rhetoric which she has offered in US law schools (including the William S. Boyd School of Law at the University of Nevada) for a number of years. In 'Studying and Teaching "Law as Rhetoric": A Place to Stand' 16 J. Legal Writing 3 (2010) 64, Professor Berger stresses that rhetorical education does more than improve students' skills. It can stir and steer 'students' natural ability to imagine and invent, and it may enable them to better listen to alternative views and to speak in their own voices' (at p.10). 
opens by asking 'How does legal education fail students?'. ${ }^{3}$ The subtitle to the first section indicates the main thrust of his answer: 'Law's Neglect of Rhetoric' ${ }^{4}$ Another, and related, inspiration for the module was the sense that student mooting, which at my university has been a largely extra-curricular activity, would be enhanced by the scholarly context of a dedicated module with its emphasis on set readings, research tasks, group work and input from academic staff. Related to this, it was intended that the module should give experienced extra-curricular mooters a chance to gain assessment credit towards their degree as a reward for their impressive investment in mooting exercises.

In its first iteration, the module was assessed by requiring each student to submit an individual reflective journal (assessed for $50 \%$ of the module marks); a copy of their outline moot arguments (having more meat to it than a standard moot 'skeleton', assessed for 20\%); and by requiring each student to perform their allocated part in a video-recorded moot exercise (30\%). Students were encouraged to include post-moot reflections on their performance in their reflective journals. In 2017, the second year of delivery, the assessment was simplified to two components: the reflective journal (50\%) and the moot (documents and performance, $50 \%$ ). The quality of the reflective journals has been generally most impressive and in some cases astoundingly attractive and produced with real creative flair. Students are asked invited to supply a photographic record of these precious and unique personal artefacts, as insurance against the risk of loss. These photographs also allow the external examiner to peruse the journals without exposing them to postal risk. The vast majority of the journals are hand-written, which in itself is practice in a dying art. In feedback to one student who

\footnotetext{
357 Loyola L. Rev. 135 (2011).

${ }^{4}$ See, further, Francis J. Mootz III, Rhetorical Knowledge in Legal Practice and Critical Legal Theory (Tuscaloosa, The University of Alabama Press 2006).
} 
submitted a typed (and otherwise very attractive) journal, I suggested that they had missed an opportunity to demonstrate the human touch that makes the best rhetoric most effective. Some journals even included pieces of the students' own original artwork and it was clear that the majority had relished the opportunity to explore the possibilities suggested by the presence of 'art' in the module's title. When it came to the difficult process of ascribing a mark to the moot performance, the journals were useful in giving me a contextual appreciation for each student's educational journey to and through the module. I could reward according to the student's engagement with the process as much as for the stand-alone quality of the product. The students were starting from different points on the road to becoming effective, ethical advocates. Some had begun as expert mooters; others had set themselves the challenge of trying something new. One brave student was a philosophy undergraduate with an aspiration to practice law but no prior experience in handling legal materials. Each student received a lengthy document giving careful personal feedback on every assessed aspect of the module.

What I could not have anticipated when I proposed the new module in 2015 is that 2016 would turn out to be so momentous a year in the history of legal and political rhetoric. The ten-week autumn term in which the module was first delivered was bisected by the election of President Donald Trump in the United States and concluded with the televised hearings in the so-called 'Brexit' case in the United Kingdom Supreme Court. ${ }^{5}$ If the need for a more critical and scholarly appreciation of the rhetorical arts of persuasion had not been apparent at the outset of the module, it was glaringly obvious by the end. The Right Honourable Lord Dyson, Master of the Rolls, in his foreword to Whitfield's The Art of

\footnotetext{
${ }^{5} R$ (on the application of Miller and Dos Santos) v Secretary of State for Exiting the
} European Union [2017] UKSC 5. 
Persuasion, describes the contemporary importance of classical rhetoric this way:

the ancients - Aristotle, Cicero, Quintilian - articulated with great brilliance what actually goes into making a speech or written submission compelling and persuasive. Their emphasis on the importance of literacy and the good use of language, on the clear structure of arguments and on attractive delivery, has real resonance in the world of today.

Quite apart from the practical need for a better legal profession, public respect for the legal profession, the judiciary and the entire justice system depends upon a sophisticated awareness of persuasive arts. As does the health of the legislature. Since 1979, lawyers have consistently made up around one-third of professionally qualified MPs. ${ }^{6}$ In 2015, the proportion was almost one-half: of 194 professionally qualified MPs, 51 were solicitors and 38 were barristers. Barrister MPs have nearly always outnumbered solicitor MPs, the 2015 ratio being the greatest advantage that solicitor MPs have had over barrister MPs since 1979.

Lord Denning was of the opinion that 'judges should so handle precedent - and should so interpret statutes - as to do justice - in a way fitted to the needs of the times in which we live'. ${ }^{7}$ Lord Denning's metaphor of handling (itself a piece of exemplary rhetoric) has positive and negative connotations. The positive sense is that a judge, and by implication an advocate, should not be a formalistic functionary but should be a humane, reflective practitioner of an art somewhat akin to a manual craft - hence the presence of 'art' in the title

\footnotetext{
${ }^{6}$ Social background of MPs 1979-2017, House of Commons Briefing Paper, CBP-7483 (28
} September 2016).

${ }^{7}$ Alfred Denning, The Family Story (London, Butterworths 1981) at 177. 
of my module and of Adrian Whitfield's book. Not that the presence of the word 'art' in the title to an advocacy manual necessarily implies that the author conceives the advocate's craft in rhetorical terms. Richard Du Cann's The Art of the Advocate makes only one, perhaps dismissive, reference to 'plain rhetoric', ${ }^{8}$ and Joseph Wesley Donovan's Skill in trials: containing a variety of civil and criminal cases won by the art of advocates, which was popular in the Unites States at the turn of the century, makes no express reference to rhetoric. ${ }^{9}$ The negative connotation of Lord Denning's 'handling' metaphor, is that it might seem to encourage manipulation - with its etymological sense of working with the hands. Arguably, though, manual craft and manipulation come to pretty much the same thing and neither is good nor bad except (to adopt Hamlet) 'thinking makes it so' (2.2.250). ${ }^{10}$ Lord Denning's creative approach to precedent and his willingness to bend the law to the justice of a case will seem to some like crafty manipulation; to others it will be regarded as way of handling rules as tools to serve justice - not artifice, but a judicial art. In a moot exercise, where mooting skill is the very thing assessed and in which, rightly or wrongly, it is possible for the mooter to succeed even when they lose the legal argument, it is especially important to excel in the arts and crafts of persuasion. To win the moot you have to win the judge. Of course, this 'art' is one which in practice works best when it is, or appears to be, most natural; just as the most convincing acting tends to be the most naturalistic. The relation of art to

\footnotetext{
${ }^{8}$ Richard Du Cann, The Art of the Advocate (Harmondsworth, Penguin Law 1993) (first published as a Pelican Original in 1964).

${ }^{9}$ Rochester, N.Y: Williamson Law Book Co, 1899.

${ }^{10}$ William Shakespeare, Hamlet, The Arden Shakespeare, 3rd series, Ann Thomson and Neil Taylor (eds) (London, Bloomsbury 2006).
} 
nature is a puzzle that has exercised rhetoricians since at least as far back as Cicero. ${ }^{11}$ Perhaps one solution lies in an appreciation of the relationship between practice and habit - the ideal being technically expert practice that becomes the advocate's second nature. In 'Law as Rhetoric, Rhetoric as Law: The Arts of Cultural and Communal Life' (another appearance of 'art' in the title of an article on legal rhetoric), ${ }^{12}$ James Boyd White, wrote:

I want to start by thinking of law not as an objective reality in an imagined social world, not as a part of a constructed cosmology, but from the point of view of those who actually engage in its processes, as something we do and something we teach. This is a way of looking at law as an activity, and in particular as rhetorical activity. ${ }^{13}$

What James Boyd started and still passionately advocates, I hope in a small way to continue through the module The Art of Advocacy. 'Practical' has long been something of a suspect word in the legal academy - for almost as long, perhaps, as 'academic' has been a suspect word in legal practice - but this largely comes down to the presumed incommensurability of critical theory with the routines of practical technique. Only when legal practice is reimagined as the creative art of moving minds through rhetorical performance do the deep and ancient connections between legal practice and critical, ethical thought become obvious. We will then see that 'moving' minds is not coercive, but communal. We move others when we ourselves are open to be moved and when we are able to imagine ways of moving. Indeed,

\footnotetext{
${ }^{11}$ See, for example, Joy Connolly, The State of Speech: Rhetoric and Political Thought in Ancient Rome (Princeton, Princeton University Press 2007).

12 52(3) University of Chicago Law Review (Summer, 1985) 684-702.

${ }^{13}$ Ibid., at 688.
} 
the rhetorical outcome of a persuaded mind is perhaps not so important as the rhetorical processes through which minds are enabled to meet. One of the principal mottos of How to Moot: A Student Guide to Mooting, which I co-wrote with John Snape,${ }^{14}$ is the reminder that 'mooting is meeting'.

There are at least two major obstacles barring the bridge that would connect legal theory to legal practice by way of legal rhetorical art. Before I come to these, we can note as a third obstacle the practical one which we nowadays, using a rather sinister Benthamite metaphor, call 'human resources'. Tutors, especially those preoccupied with legal practice or scholarly research and writing, all too often lack a sufficiently strong incentive to prioritize time-intensive modes of teaching. Compared to mooting and performance-based exercises, lectures cost less in terms of the teacher's time and effort. It has been observed that even in the early modern heyday of rhetorical legal education, when 'the judges' orders of 1574 stated that no student should be permitted to remain in residence if he did not "exercise Moots and other exercises of learning' within three years after admission. The benchers had no incentive to implement this very mild requirement, and there is no evidence that they made any attempt to do so'. ${ }^{15}$ I will now turn to consider two more fundamental obstacles in the way of rhetoric's potential to revitalise legal thought and practice.

The first obstacle is the law's habitual denigration and disavowal of its own rhetorical traditions and its own rhetorical practices (by which I mean lawyers' habitual denial of their own rhetoric). Peter Goodrich attributes 'the rise of the formalist and essentially patriarchal myth of a determinate and univocal language of legal authority' to the 'repression' of

\footnotetext{
${ }^{14}$ How to Moot: A Student Guide to Mooting 2nd edn (Oxford, OUP 2010) 20.

${ }^{15}$ Wilfrid Prest, 'Legal Education of the Gentry at the Inns of Court, 1560-1640', (1967) 38(1) Past Present 20-39, at 29.
} 
rhetoric, which he calls 'the excluded discipline'. ${ }^{16}$ Gerald B. Wetlaufer provides another elegant summary of the problem, writing that 'the particular rhetoric that law embraces is... one that relies... upon the denial that it is rhetoric that is being done' ${ }^{17}$ Since Aristotle, and until the Enlightenment, rhetoric was regarded not as a false mode of argument but as an art that is 'just' in its capacity to be true to the agony, beauty and complexity of human affairs. Nowadays, we are accustomed to politicians talking of the 'massive gap between rhetoric and reality ${ }^{918}$ without acknowledging the irony that they are using rhetorical devices

${ }^{16}$ Legal Discourse: Studies in Linguistics, Rhetoric and Legal Analysis (New York, St Martin's Press 1987), at 90. Alongside the rhetorical writings of Peter Goodrich, I would especially recommend the works of James Boyd White, including The Legal Imagination (1973) (Colorado, Aspen Publishers 2018); Heracles' Bow: Essays on the Rhetoric and Poetics of the Law (University of Wisconsin Press, Madison 1985); The Edge of Meaning (The University of Chicago Press, Chicago 2001); Living Speech (Princeton University Press, Princeton 2006). White and Goodrich both contribute to Austin Sarat, Thomas R. Kearns (eds), The Rhetoric of Law (The University of Michigan Press, Ann Arbor 1996). Marianne Constable's Our Word is Our Bond: How Legal Speech Acts (Stanford University Press, Stanford 2014) is a recent and valuable contribution to the field. Of course the internet has made it easy nowadays to return to the fountain head from which much of this scholarship first sprung. Cicero's works, for example, are easily accessible online in the original Latin with parallel English translation. The reader is directed to such works as De Inventione; De Optimo Genere Oratorum; Topica; De Oratore.

${ }^{17}$ Gerald B. Wetlaufer. 'Rhetoric and Its Denial in Legal Discourse.' Virginia Law Review 76 (1990): 1545-97, 1555.

${ }^{18}$ Shadow home secretary Yvette Cooper http://www.bbc.co.uk/news/uk-32013794. 
of metaphor, hyperbole and alliteration in making such a statement. Likewise, the present dominant mode of legal thought denies its own part in founding and developing the rhetorical tradition.

A second, and related, obstacle to the renaissance of rhetorical art in law is the tendency amongst many lawyers, although perhaps not so much amongst the best practising advocates, to suppose that the proper outcome of legal disputes is and ought to be scientifically predictable according to the rational application of rules regardless of social context and human sentiment. Writing about 'Vico's Ingenious Method of Rhetorical Education', ${ }^{19}$ Francis J. Mootz reminds us that in Vico's 1708 oration On the Study Methods of Our Time,${ }^{20} \mathrm{Vico}$, responding to what we now call the scientific Enlightenment, 'fully appreciated the power of the Cartesian method, but he also anticipated that its power would prove to be overbearing':

Vico begins his oration with a reminder that all human knowledge is partial and fallible, and therefore that we should always be ready to assess our beliefs and correct them. However, he exhorts his audience to recognize that Cartesian radical doubt undermines not only false beliefs that should be discarded but also beliefs grounded in the probable, without which we could not live. ${ }^{21}$

${ }^{19}$ Francis J. Mootz III, 'Vico, Llewellyn and the Task of Legal Education', 57 Loyola L. Rev. $135(2011)$.

${ }^{20}$ Giambattista Vico, On the Study Methods of Our Time (1709) Elio Gianturco trans. (Cornell University Press, Ithaca 1990)

21 'Vico, Llewellyn and the Task', at 137. 
Despite Vico's warning, law subscribes at present to a paradigm of scientific logic and laboratory predictability that is consistently belied and thwarted by the messy reality of law's encounters with social life. Utilitarian post-Enlightenment orthodoxy regarded rhetoric as an 'off-shoot from logic'. These are the words of Richard Whately, who had as one of his aims to 'lay down some rules respecting the excitement and management of...the Passions' ${ }^{22}$ Neil MacCormick's Rhetoric and the Rule of $\mathrm{Law}^{23}$ extends this tradition of rhetorical rationality into the practical traditions of legal argument and judicial reasonableness. In this book MacCormick is committed, like the German jurist Robert Alexy, to 'the standing of law as a scientific discipline'. ${ }^{24}$ His faith in law as systematic science (Rechtswissenschaft) leads him to neglect law's nature as an imaginative art and its potential to be 'the queen of the humanities' ${ }^{25}$ This is a most serious species of neglect, for who will disagree with James Boyd White that 'imagination is the root of justice' ${ }^{26}$ Willem Witteveen, reflecting on White's work, considered 'Imagining Rhetoric' to be inseparable from the hope of 'Approaching Justice'. ${ }^{27}$ Going back to the early modern renaissance of classical thought we

${ }^{22}$ Elements of Rhetoric (1828) (From the last enlarged and revised edition - Southern Methodist Publishing House, Nashville 1861) 18-19.

${ }^{23}$ Neil MacCormick, Rhetoric and the Rule of Law (OUP, Oxford 2005).

${ }^{24}$ MacCormick ibid at 279.

${ }^{25}$ Charles A. Reich, 'Toward the Humanistic Study of Law', Yale Law Journal, 74:8 (1965) $1402,1408$.

${ }^{26}$ James Boyd White, Living Speech (n16) 90.

${ }^{27}$ Willem Witteveen, 'Imagining Rhetoric, Approaching Justice' in Julen Etxabe and Gary Watt (eds), Living in a Law Transformed: Encounters with the Works of James Boyd White (Michigan University Press, Ann Arbor 2014) pp. 52-67. 
find that the leading minds were under no illusion as to the practical difference between science and art in matters of human persuasion. As Francis Bacon put it, when writing 'On Rhetoric, or the Art of Eloquence' in his 1605 work The Advancement of Learning: 'Rhetoric is the application of reason to imagination for the better moving of the will. It is not solid reasoning of the kind science exhibits' ${ }^{28}$ Systematic scientific method has achieved and continues to achieve great things, but it has shown itself a poor predictor of political elections and, despite some algorithmic capacity to analyse language used in reported judgments and to guess the decision that was made, ${ }^{29}$ there is no scientific way to predict which side will win in an appeal court trial, still less whether they will win by a majority or a unanimous decision. Where human will and imagination are involved in judgment, we can expect predictions to be defied. None of this is to suggest a trite distinction between science and imagination. Imagination frequently supplies the best science, and this is especially so in the artificial world of the law. It has been said, for instance, that '[1]aw is a major area where metaphor is made real' ${ }^{30}$ When seeking to tell the story of the abstract human idea of 'justice', what better tool could there be than the materiality of metaphor? For example, there has hardly been a more influential metaphor in modern moral jurisprudence than Rawls' 'veil of ignorance' ${ }^{31}$ How rhetorically powerful, and necessary, it is to employ metaphor to convey

\footnotetext{
${ }^{28}$ II.xviii. 2.

${ }^{29} \mathrm{http} / / /$ www.ucl.ac.uk/news/news-articles/1016/241016-AI-predicts-outcomes-humanrights- trials.

${ }^{30}$ G Lakoff, 'Contemporary Theory of Metaphor' in Andrew Ortony (ed), Metaphor and Thought 2nd edn (Cambridge University Press, Cambridge 1993) 202-51, 243

${ }^{31}$ John Rawls, A Theory of Justice (Harvard University Press, Cambridge MA 1971), chapter 3, part 24.
} 
our deepest sense of justice; and how telling it is that Rawls's metaphor requires the judicious moral actor to employ imagination to produce a fantastic scene in which the judge is unaware of any personal similarity (for example gender or race) that he or she might have to the person being judged.

According to Quintilian, of all the rhetorical tropes, metaphor is 'the commonest and by far the most beautiful' ${ }^{32}$ Its beauty lies in its capacity to express what really matters in a way that is really meaningful. Metaphor exemplifies the fact that rhetorical form is not an ornamental distraction from the scientific substance of the matter. When rhetoric contributes to the hardest, tragic cases of human encounter with law and legal judgment, 'It's Not All About Pretty'. ${ }^{33}$ The best legal rhetoric, like the best poetry and the most moving drama, has capacity to reach the points that a merely logical argument cannot. Even where the subject matter is unpleasant, the handling of the matter must be as humane as possible. This means that persuasive speech should be concerned not only to promote ethical outcomes (moving people away from the worst, and hopefully towards the better) but also that the outcomes of persuasive speech - for example, a judicial judgment (itself another form of persuasive speech) - should be performed sympathetically (with pathos or fellow-feeling) rather than coldly and dispassionately. As the early modern judge and rhetorician Thomas Wilson advised, 'to delight is needful, without the which weighty matters will not be heard at all'. He approved of the rhetorician who 'will ever, mingle sweet among the sower, be he Preacher,

\footnotetext{
${ }^{32}$ Institutio Oratoria (8.6) (trans HE Butler) (Harvard University Press, Cambridge MA
} 1921) book III, 301-0.

${ }^{33}$ Julen Etxabe, 'It's Not All About Pretty: Human Rights Adjudication in a Life and Death Situation' in Julen Etxabe and Gary Watt (eds), Living in a Law (n27), pp. 68-88. 
Lawyer, yea, or Cooke either hardly, when he dresseth a good dish of meat' ${ }^{34}$ When Thomas Wilson refers to the sweetness of a lawyer's words he is alluding to the capacity of rhetoric to persuade ('per-sweet'). Since the Enlightenment, judicial judgments and legal scholarship in Common Law jurisdictions have all too often been concerned to strip away the decorative aspect of judicial judgments in order to come to the essential meat of the matter. Justice Kirby's attitude is typical, when (commenting on the urgency of legal business) he recommends that '[i]ts expositions should be as brief as possible. They should be confined to matters strictly relevant to the judicial purpose. In a struggle between accuracy, timeliness and elegance, the last must always give way'. ${ }^{35}$ The problem with this method is that it assumes, as Wilson's metaphor might imply, that the dressing of a decision can be easily removed from the meat. James Boyd White argues, to the contrary, that our rhetoric - the way we think and talk and act and persuade - constitutes who we are and what we become. The great American Judge Benjamin Cardozo expressed the seeds of something similar in his essay 'Law and Literature':

We are merely wasting time, so many will inform us, if we bother about form when only substance is important. I suppose this might be true if any one could tell us where substance ends and form begins...Form is not something added to substance as a mere protuberant adornment. ${ }^{36}$

\footnotetext{
${ }^{34}$ Thomas Wilson, Arte of Rhetorique (1560) G. H. Mair ed, Book II (Clarendon Press, Oxford 1909) 99. (Spelling modernised.)

${ }^{35}$ Michael Kirby, 'Bray's impact on Australian jurisprudence' in Wilfrid Prest (ed) A Portrait of John Bray: Law, Letters, Life (Wakefield Press, Kent Town 1997) 93, 108. 36 'Law and Literature' 48 Yale L J (1938-1939) 489, 490.
} 
It follows that, since judges cannot judge without resort to such rhetorical aids as metaphor, it is incumbent upon them to choose their metaphors carefully. In this vein, Adrian Whitfield QC advises student advocates that:

There is more to advocacy than cold reasoning. Your aim is to make your presentation as attractive as the facts and the law permit. You must run the case in a way which makes it a pleasure for the tribunal to listen to you, and compels it to respect you and, by extension, your case.

Of course, metaphors, must be employed with caution. One student on my module gave the example of a tort case in which a woman consented to an operation on her back and in which the surgeon failed to warn her of a small chance of a seriously adverse outcome. ${ }^{37}$ Lord Hoffmann belittled the woman's suggestion that she might have fared better with another surgeon in another hospital. His Lordship dismissed this as 'irrelevant' and 'as logical as saying that if one had been told, on entering a casino, that the odds on No 7 coming up at roulette were only 1 in 37 , one would have gone away and come back next week or gone to a different casino'. ${ }^{38}$ Lord Walker disagreed. He pointed out the weakness of the casino metaphor:

My noble and learned friend Lord Hoffmann...puts forward a vivid analogy from roulette. But the 1 in 37 chance of a particular number coming up (assuming the

${ }^{37}$ Chester v Afshar [2004] UKHL 41.

${ }^{38}$ Ibid at para. 31. 
roulette wheel to be properly made and operated) is a matter of simple and precise mathematical calculation. By contrast the chance of nerve damage occurring (without negligence) during lumbar surgery can be calculated only with hindsight, as a more or less accurate approximation, by compiling and analysing statistics as to the outcome of that type of surgery. The risk no doubt varies with the skill and experience of the surgeon, the severity of the patient's condition, and the precise type of surgery undertaken...I would not accept, on the strength of the roulette analogy, that these should be regarded as changing the scenario only in some irrelevant detail. Nor, I suspect, would anyone who was suffering the same pain and distress as Miss Chester was suffering, and who was faced with the same dilemma as she faced... ${ }^{39}$

Lord Walker demonstrates not only that the use of a metaphor can catch the user out, but that it is better for a lawyer to be technically expert and humane than to be merely technically expert. In employing the statistical and mechanical metaphor of the roulette wheel, Lord Hoffmann lost sight of the fact that he was talking about a woman in great pain and distress. Lord Walker, in contrast, made it clear that he had her at the forefront of his mind. Even if the legal diagnosis and decision has to be tragic, as it was in Re A (Separation of Conjoined Twins), ${ }^{40}$ and as it is in any such case of genuine dilemma, rhetorical care for the form of judicial speech is always desirable. When a decision is expressed humanely the cultural outcome changes even if the scientific outcome (in this case, to authorise surgical separation) does not.

\footnotetext{
${ }^{39}$ Ibid. paras. 97-98.

${ }^{40}$ [2001] Fam 147, Court of Appeal.
} 
Re A (Separation of Conjoined Twins) is a case I keep returning to. There the court was faced with a choice between two undesirable outcomes. The twins were expected to die very soon if not separated and, if surgically separated, the weaker would die immediately while the stronger would have a reasonable chance of normal lifespan. Ward LJ, the leading judge in that case, was genuine in his expression of sympathy but his lawyerly linguistic habits led him to express the twins' shared plight in terms of adversarial conflict and to describe the weaker twin as 'parasitic' on the stronger. The weaker was described as one who 'sucks the lifeblood' of the stronger. He imagined that the stronger, if she could speak, would have said 'stop it...you're killing me'. ${ }^{41}$ Without altering his decision to authorise surgical separation, the judge might have imagined the weaker to say, for example, 'I want to release you to live for us both'. A proper outcome in this case should be formed as much in a fitting story for the surviving twin to live with as in the narrowly pronounced decision to cut or not to cut. The judge advanced rhetorical logos at the expenses of rhetorical pathos, when he ought to have advanced both. As James Boyd White observed, when writing about decisions in the US Supreme Court, 'the good opinion, like the Attic theater, resists the language of cliché and slogan and insists instead upon recognizing the pressure of real and human experience'. ${ }^{42}$ In Rhetoric and the Rule of Law, Neil MacCormick's engagement with Re A (Separation of Conjoined Twins) amplified the logical errors inherent in the court's approach even as it purported to suppress them. Consider, for example, how factually inaccurate is his assumption (duplicated from Ward LJ's analysis) that the weaker twin's 'continuing life will cause [the stronger twin's] death' ${ }^{43}$ In what sense can physical conjuncture admit the

\footnotetext{
${ }^{41}$ Ibid., at p.197.

${ }^{42}$ Living Speech (n16) 175.

${ }^{43}$ Rhetoric and the Rule of Law (n23) at p.91.
} 
possibility that one conjoined twin is the 'cause' of the other's death? Such a possibility makes perfect sense if one is committed to regarding conjoined twins as individuals in a legalistic state of adversarial competition, but talk of causation makes no sense at all in light of the reality of the twins' intimately - and temporally co-original - shared state. By referring to 'each' of the twins and their 'individual' lives, the judgment of Ward LJ separated the twins rhetorically as a prelude to separating them surgically. MacCormick's uncritical repetition of the judge's language did nothing to critique the causal error or the judge's prejudgment of the issue.

If the task of the judge is to speak justice not merely to the mind, but to the heart of the matter, so the task of an advocate is to win the 'heart and mind' of the judge, jury or other audience. To win the 'heart and mind' might seem like a modern soundbite - it has been frequently used, and sometimes abused, to describe modern military efforts to win political peace with the local population even while seeking to win a war - but it has long been a staple of rhetorical wisdom. It was already old when Shakespeare's Mark Antony used it in Julius Caesar: 'if I were disposed to stir / Your hearts and minds to mutiny and rage, / I should do Brutus wrong, and Cassius wrong' (3.2.122-124). ${ }^{44}$

Student advocates in the module The Art of Advocacy are encouraged to appreciate that to win we have to attend to the way we win, why we win, and what we win. If rhetoric has something of a bad name nowadays, this is attributable in large part to the fact that politicians and other advocates seek to win without regard to the way, the why and the what.

\footnotetext{
${ }^{44}$ All references to Julius Caesar are from David Daniell (ed.), Julius Caesar, The Arden Shakespeare, 3rd series (Bloomsbury, London 1998). On Shakespeare's rhetoric in Julius Caesar, see Gary Watt, Shakespeare's Acts of Will: Law, Testament and Properties of Performance Bloomsbury Arden Shakespeare (Bloomsbury, London 2016), chapter 4.
} 
Tony Blair, the former Prime Minister and former lawyer, is currently engaged in a zealous mission to reverse the outcome of the United Kingdom's EU referendum - the so-called 'Brexit' vote. In his speech 'The Battle for Britain' (note the military metaphor), he asserted that it all comes down to 'winning by force of argument' ${ }^{45}$ Even with the caveat of his next words 'not by the argument of force, without fear' (note the duplication of 'force' and the triplicate ' $\mathrm{f}$ '), does this not sound like the language of man who regards rhetoric as a weapon in a war of words? Thomas Wilson described rhetoric rather differently, as the art of 'moving pity, and stirring men to show mercy' (The Art of Rhetoric, 1553). It will be recalled that in Shakespeare's Julius Caesar, Mark Antony wins his rhetorical contest with Brutus, but the tragedy is that as 'Antony wins... Rome loses' ${ }^{46}$ He stirred up the hearts and minds of the mob into a frenzy and the result was a riot and violent bloodshed. Even a poet is killed by mistake - a warning from Shakespeare, perhaps, that nobody is safe when rhetoric goes rogue.

Shakespeare was a poet concerned with theatrical performance, and so too are all rhetoricians - from classroom teachers to political orators. The Greek adjective rhetorikos denoted the profession of the rhetor or orator who were the public speakers and legal advocates of ancient Greece. The word ultimately derives from Proto-Indo-European for the spoken word $\left({ }^{*}\right.$ wretor $)$. However, it is a mistake to suppose that rhetoric is only concerned with words. Rhetoric is the art of words, and silences, in performance. Democratic politics is constituted, as it has been since Ancient Greece, according to ideals of rhetorical debate and especially the rhetorical mode of the legal trial. Even with the decline of traditional political parties, politics is still about taking opposing sides like parties to a legal action and it is, by

\footnotetext{
4517 February 2017.

${ }^{46}$ Jennifer Richards, Rhetoric, The New Critical Idiom (Routledge, Abingdon 2008) 93.
} 
the same rhetorical tradition, about playing opposing parts in a drama. The ancient Greek ‘jury' sat in theatres in their hundreds and voted in a manner akin to a simple yes or no referendum. This mirrored, or maybe preceded, the use of theatres for Greek Thespian drama. Even today, law 'operates through investitures that may well be theatrical . . . but are also, and everywhere, performative'. ${ }^{47}$ As Sir Edward Parry once opined: 'To observe an analogy between drama and the law does not seek to exalt the art or to degrade the science'. ${ }^{48}$ Politics is trial and trial is performance, all three being connected since their earliest origins by the shared art of rhetoric. ${ }^{49}$ Despite Hamlet's bookish preoccupation with 'words, words, words' (2.2.189), his advice to the travelling troupe of theatrical players who visit Elsinore comes straight out of the rhetoric manual: 'suit the action to the word' (3.2.17). 'Actio' described the rhetorical gestures of orators and 'action' described legal proceedings long before 'acting' became a byword for playing in the public playhouses. ${ }^{50}$ Some years ago, Balkin and Levinson argued that "we think it is time to replace the study of law as literature with the more general study of law as a performing art' ${ }^{51}$ At the very least the time has come to advance the study of law as literature towards, and alongside, a more specific study of law as

${ }^{47}$ Alan Read, Theatre \& Law, 2015, p.41. Reviewed by Sean Mulcahy, 'Law and Culture' 42(1) Alternative Law Journal (2017) 77 - 83,

${ }^{48}$ The Drama of the Law (T.F. Unwin, Limited, London 1924) 7.

${ }^{49}$ A point also made by Paul Raffield in the opening of The Art of Law in Shakespeare (Hart, Oxford 2016). Another book expressly concerned with the lawyer's rhetorical 'art'.

${ }^{50}$ On the terminology of 'acting', see Andrew Gurr, The Shakespearean Stage, 1574-1642, 4th edn (Cambridge University Press, Cambridge 2009), 118.

51 'Law as Performance' in Michael Freeman and Andrew D. E. Lewis (eds), Law and Literature (Oxford University Press, Oxford 1999) 729-751. 
an art of rhetorical performance.

According to Wayne C. Booth, rhetoric embraces all influential social performances. His description demonstrates how rhetoric covers ground that modern experimental and social psychologists now tread on. ${ }^{52}$ It encompasses, he says:

the entire range of resources that human beings share for producing effects on one another...Rhetoric is employed at every moment when one human being intends to produce, through the use of signs or symbols, some effect on another - by words, or facial expressions, or gestures, or any symbolic skill of any kind. Are you not seeking rhetorical effect when you either smile or scowl or shout back at someone who has just insulted you $?^{53}$

As lawyers deny the rhetorical dimension of their art, so they especially deny the performative or theatrical dimension of their rhetoric. Even the ancient rhetoricians expressly cautioned against confusion between acting and oratory, which was surely to protest too much against the inevitable similarity between two branches on the same rhetorical tree. The

\footnotetext{
${ }^{52}$ See, for example, Derek Hook, Bradley Franks, Martin W. Bauer (eds), The Social Psychology of Communication (Palgrave Macmillan, Basingstoke 2011), which includes a chapter by Martin W. Bauer and Vlad P. Glăveanu on 'Communication as Rhetoric and Argumentation' (pp.209-228). The abstract to that chapter observes that 'Rhetoric is both an art and a science that everyone, in different contexts of daily life - at home, at school, at the market, at the workplace and so on — draws from, more or less consciously'.

${ }^{53}$ Rhetoric of RHETORIC: The Quest for Effective Communication (Blackwell Publishing, Oxford 2014), preface xi.
} 
ancient rhetoricians encouraged the use of stage, costume, gesture, passion and nuanced vocal delivery, and sometimes, it is said, took lessons from actors. We must conclude that their disclaimer of theatrical dramatics was all part of their act. The disclaimer continues in every generation. In the US, there was resistance to the first proposals to televise courtroom trials. It is an interesting exercise to invite today's students to respond to the following objection raised in 1962 by the then Dean of Harvard Law School, the first line of which is surely recalling Shakespeare's 'All the world's a stage, / And all the men and women merely players' $(2.7 .140-1):{ }^{54}$

A courtroom is not a stage: and witnesses and lawyers, and judges and juries and parties, are not players. A trial is not a drama, and it is not held for public delectation, or even public information. It is held for the solemn purpose of endeavoring to ascertain the truth - and very careful safeguards have been devised out of the experience of many years to facilitate that process. it can hardly be denied that if this process is broadcast or televised, it will be distorted. Some witnesses will be frightened some will want to show off, or will show off, despite themselves. Some lawyers will 'ham it up'. Some judges will be unable to forget that a million eyes are upon them. How can we say that our primary concern is the equal administration of justice if we allow this to be done? ${ }^{55}$

\footnotetext{
${ }^{54}$ As You Like It, The Arden Shakespeare, 3rd series, Juliet Dusinberre (ed.) (Bloomsbury, London 2006).

${ }^{55}$ Erwin N. Griswold, 'The Standards of the Legal Profession: Canon 35 Should Not Be Surrendered', 48 ABA Journal 615-618 (1962), 616.
} 
We might agree that some recent TV shows specialising in the broadcast of courtroom proceedings do little to promote the dignity of judicial proceedings, but they have, perhaps, served to make the process seem more accessible and approachable. One part of the preceding quote that I cannot agree with is the oft-repeated myth that trials are held for the 'purpose of endeavoring to ascertain the truth'. This might be the aim of a public inquiry or a coroner's inquest of the sort that was so necessary in uncovering the institutional cover-up of the causes of the Hillsborough tragedy, but a standard judicial trial (at least in an adversarial system) does not purport to discover truth. Its expressed aim is merely to approve the most plausible, we might say the most pleasing and persuasive, factual narrative. A common law judicial trial moulds matter of fact into law's idea of fact; and in the process turns fact into fiction. Judges can do no more than observe the complexities of social reality through the distorted eyes of witnesses and the partial lens of admissible evidence. They do not discover reality as an explorer or an anthropologist might, but rather facts are made ('factus') out of a complex matrix of evidence. In a civil trial they find facts on a bare balance of probabilities a likelihood greater than fifty per cent. Thus they find fact where there may be none in fact. They find actuality in probability. The creative, performative dimension of the trial process and its method of fact-finding ('fact-making', or 'manu-fact-uring' would be a better description) is often ignored or down-played in case it is perceived to be somehow unscientific, but to observe the art in law is merely to observe that science can only take us so far - and often not very far at all - in determining the outcome of cases, especially the hardest cases in the highest courts.

The rhetorical tradition can be refined into the following golden advice to the student advocate: a judge will be most persuaded by the advocate who engages in apparently unscripted conversation with the judge; presenting arguments to the judge in a sympathetic manner, listening attentively to the judge's observations and responding appropriately to the 
judge's questions. It has been noted by one enamoured observer that the leading barrister Lord Pannick QC 'exudes a sense of calm and has the uncanny ability to make you think you understand legal doublespeak even when you don't. A Pannick attack is a thing of zen-like beauty. He doesn't need to shuffle his papers because he never forgets a reference'. ${ }^{56}$ A good advocate is always, first and foremost, a humane communicator - one who does not moot at the judge, but meets with the judge - not only through speaking, but also by listening with a sympathetic ear. The golden word is 'sympathetic'. It literally means 'with pathos'. Any good law student can draw up an argument with logos - that is, a 'logical' argument - but it takes a superior student to know how to turn a merely logical argument into a truly winning argument. The best students achieve this by pressing the logos of a logical argument whilst not neglecting pathos and ethos. An advocate's argument has pathos if it inspires the judge to feel the facts from the advocate's point of view (or from the point of view of the advocate's client). An argument that has pathos is often characterized by the quality of being emotionally moving, so if a moot judge describes an argument as 'pathetic' the advocate might almost take it as a compliment. In Shakespeare's Julius Caesar we see an example of pathos in Mark Antony's speech that wins over the crowd at Caesar's funeral. Antony persuades the crowd to side with the assassinated Caesar by saying 'when that the poor have cried, Caesar hath wept' (3.2.92). At the conclusion of Cicero's speech Pro Milone, he says:

${ }^{56}$ John Crace, 'Supreme court justices tamed in face of a Pannick attack', The Guardian 6th December 2016; discussing Lord Pannick's performance in $R$ (on the application of Miller and Dos Santos) v Secretary of State for Exiting the European Union [2017] UKSC 5. Writing extra-judicially, David Pannick is the author of two books that may be of interest to the student advocate: Judges (Oxford University Press, Oxford 1987) and Advocates (Oxford University Press, Oxford 1992). 
'I must stop now. I can no longer speak for tears - and my client has ordered that tears are not to be used in his defence' $(\mathrm{Mil}, 105)$. Of course, in a moot setting a student must be judiciously restrained in their appeal to emotions. Like sugar, it can sweeten a good argument - but, like sugar, too much will come across as sickly sweet. Ethos is an equally important element of a persuasive argument, for it is the quality that persuades the moot judge that the advocate has a desirable and sincere 'ethical attitude' - an example of this would be the advocate who demonstrates his or her personal humility, or their personal concern for social justice. I advise my students that if they want to APPEAL to the judge and win the moot, they should Always Present Pathos Ethos And Logic.

The nature of legal logic is one of the first substantive topics in the module The Art of Advocacy. The first point we puzzle over is whether the logical dimension of the law, even leaving aside all concerns of pathos and ethos, is actually rational in the way that, say, philosophy is. We quickly discover that the answer is very definitely 'no'. Law's rationality is artificial and this is down in large part to law's respect for authority. A judicial statement becomes authoritatively binding as a result of the status of the forum in which it is uttered. Regardless of its inherent logic the same statement uttered by a moot judge, say, has no binding effect in law. This is so even if the moot judge happens to be a Justice of the Supreme Court of the United Kingdom. The lawyer's phrase 'persuasive authority' is a clue to the rhetorical reality of law. A legal decision binds not by any inherent strength of logic, but according to the extent that its formal status confers precedential value. Absent any binding precedent, it all comes down to whether or not the judge is persuaded by the range of 
authorities and arguments presented by the advocate. ${ }^{57}$ In the case of a judicial statement, whether or not it is formally binding, the judge's personal reputation (an aspect of his or her ethos) can render the statement more or less persuasive despite the fact that, logically speaking, 'ad hominem' arguments are inherently suspect. In law, as also in the rest of life, a statement is for practical purposes rendered more true when the person making it is more credible.

Credibility is, however, an elusive concept. The election of Donald Trump as President of the United States of America shows that credibility is certainly not the preserve of professional lawyers, political insiders or even eloquent speakers. A billionaire property developer and television personality can come across as a man of action and defeat a legallytrained and politically experienced woman of words. I recommended to my student advocates that they should watch the US Presidential debates with the sound turned off in order to assess for themselves which speaker has the most innate appeal. Our findings frequently defy our prejudgments. Linguists have found that in the Presidential primaries the femininity of Donald Trump's voice was second only to Hillary Clinton's and that, when placed alongside such non-verbal cues as gestures and facial expressions, he was the most feminine of all the candidates. ${ }^{58}$ A female journalist for The Guardian wrote 'imagine if Donald Trump were a woman. You simply can't', ${ }^{59}$ but an experiment in political performance at New York University has imagined precisely that. Maria Guadalupe, an associate professor of

${ }^{57}$ See, generally, Joseph William Singer, 'Legal Storytelling: Persuasion' 87 Mich. L. Rev. (1989) 2442. Fabrizio Macagno and Douglas Walton. 'Argument from Analogy in Law, the Classical Tradition, and Recent Theories' Philosophy \& Rhetoric 42(2) (2009) 154-82. 58 ‘Measuring Trump’s Language’, New York Times, 14 March 2016.

${ }^{59}$ Haley Freeman, The Guardian, 27 September 2016 
economics and political science worked with Joe Salvatore, an associate professor of educational theatre, to commission an actress to play Trump 'replicating his words, gestures, body language, and tone verbatim' while a male actor did the same in the role of Clinton. ${ }^{60}$ Guadalupe and Salvatore found in rehearsal that their own preconceptions were challenged, leading them to ask what the male Clinton (actor Jonathan Gordon) was 'smiling about all the time', and did he not 'seem a little stiff, tethered to rehearsed statements at the podium', while the female Trump (actress Brenda King) 'plainspoken and confident, freely roamed the stage?'. ${ }^{61}$ In performances of their show, Her Opponent, audiences 'were shocked to find that they couldn't seem to find in Jonathan Gordon what they had admired in Hillary Clinton - or that Brenda King's clever tactics seemed to shine in moments where they'd remembered Donald Trump flailing or lashing out' ${ }^{62}$

Is it the case that actions really do speak louder than words? Mark Antony was a man of action who won acclaim as a military general and who ran ritually naked through the forum of Rome on the Lupercalia (the festival of the wolf). The Roman crowd that had gathered in the forum for the festival was most impressed to see Caesar wave away the crown that Mark Antony three times made a great show of offering him. Shakespeare takes this man of action and gives him some of the best lines, including the famous 'Friends, Romans, countrymen, lend me your ears' (3.2.74). We do not believe Mark Antony when, in Shakespeare's account, he claims to be 'no orator as Brutus is', but in President Trump's case

${ }^{60}$ Eileen Reynolds, 'What if Donald Trump and Hillary Clinton Had Swapped Genders?' 28 Feb 2017 (www.nyu.edu/about/news-publications/news/2017/march/trump-clinton-debatesgender-reversal.html) I am grateful to Sean Mulcahy for bringing this to my attention.

${ }^{61}$ Reynolds, ibid.

${ }^{62}$ Ibid. 
we do believe that he is no orator as the lawyers Hillary Clinton or Barack Obama are; we are constantly reminded of it in the litany of articles devoted to his sentence construction, use of gesture and movement. Yet it doesn't seem to matter. His actions are eloquent, and his words work. For the members of his audience 'his use of incomplete thoughts and sentence fragments has an unmediated, stream-of-consciousness feel' which serves to amplify 'the voice inside their own heads - a rich and sometimes dark stew of conversational snippets and memory scraps, random phrases and half-thoughts' ${ }^{63}$ It has been said that Donald Trump's 'cleverest trick is sounding stupid' and that he uses 'the simple language of a ten-year-old to connect with the blue-collar, dispossessed' ${ }^{64}$ The monosyllabic nature of many of his soundbites - 'drain the swamp'; 'lock her up' - makes them highly effective. Even that most celebrated of American lawyer-rhetoricians, Abraham Lincoln, was a master of using monosyllabic speech to meet with the common man or woman. One of the students on the module made reference in her reflective journal to the fact that Lincoln's Gettysburg Address was largely monosyllabic. The celebrated opening clause 'Four score and seven years ago our fathers brought forth' is especially terse and contains the weighty earthiness of a repeated 'ore' sound, which is a technique Shakespeare also used to great poetic and rhetorical effect. ${ }^{65}$ Lincoln could have pressed the point by saying 'forefathers' instead of 'fathers', but he perfectly judged that this would make the art too obvious and thereby rob it of its persuasive power. The word 'forefathers' is skilfully elided, with the result that the hearer

\footnotetext{
${ }^{63}$ Gwenda Blair, 'Inside the mind of Donald Trump' The Guardian, 12 November 2016. ${ }^{64}$ Ben MacIntyre, 'Trump's cleverest trick is sounding stupid - Republican frontrunner uses the simple language of a ten-year-old to connect with the blue-collar, dispossessed' The
} Times 13 May 2016.

${ }^{65}$ Watt, Shakespeare's Acts of Will (n44), pp.181-201, 'Law and the "or"'. 
instinctively and imaginatively infers it. The challenge for student advocates and their tutors is to work out how study, practice and art can enhance natural technique whilst keeping the appearance of unstudied, unpractised artlessness. In an interview for Humans of New York, ${ }^{66}$ Hillary Clinton gave the following fascinating insight into the rhetorical art of naturalistic communication. Notice how she begins with her own version of 'I am not an-orator as Brutus is':

I'm not Barack Obama. I'm not Bill Clinton. Both of them carry themselves with a naturalness that is very appealing to audiences. But I'm married to one and I've worked for the other, so I know how hard they work at being natural. It's not something they just dial in. They work and they practice what they're going to say. It's not that they're trying to be somebody else. But it's hard work to present yourself in the best possible way. You have to communicate in a way that people say: 'OK, I get her.' And that can be more difficult for a woman. Because who are your models?

One model that Hillary Clinton could look to is (to put it in her own style) the woman married to Barack Obama. Michelle Obama, another lawyer, exemplifies the ability to make art serve and enhance, rather than distract from, a rhetorician's natural warmth and ease of communication. ${ }^{67}$ Clinton's appropriation of the rhetoric of Shakespeare's Julius Caesar was not a one-off. In a tweet on 2 May 2017, she shared an emotionally moving news item with

\footnotetext{
${ }^{66} \mathrm{http} / / / \mathrm{www}$. humansofnewyork.com.

${ }^{67}$ The full transcript of her celebrated New Hampshire speech can be found here: https://www.theguardian.com/us-news/2016/oct/14/michelle-obama-speech-transcript-
} donald-trump. The reader will note that Michelle Obama never once mentions Donald Trump by name. 
her followers whilst warning them that it might make them cry. Her phrase 'Watch \& prepare to tear up' is practically a paraphrase of Mark Antony's (Shakespeare's) 'If you have tears, prepare to shed them now' (Julius Caesar, 3.2.167). A problem with Hillary Clinton's rhetoric during her Presidential campaign - indeed, it has been a frequent critique throughout her political career - is that it came across as too lawyerly, too studied. At one point, and with no apparent sense of irony, she used the rhetorical device of antithesis to criticise Republican rhetoric, saying 'it's clear tonight that the stakes in this election have never been higher, and the rhetoric we're hearing on the other side has never been lower'. She even lowered the pitch of her voice on the final word and her audience responded with a supportive groan. ${ }^{68}$ Having just dismissed 'the other side' like a true adversarial lawyer, she complained that 'dividing America between us and them is wrong'. This is an awkward juxtaposition and, as such, a failure of rhetorical 'arrangement'. It is also problematic in that it requires the audience to ponder a distracting paradox: how to conduct bi-partisan politics without dividing between 'us' and 'them'. A good advocate knows that their audience should not be prompted to ask questions with unpredictable, or unattainable, answers. It does not produce a persuasive sense of satisfaction. Michelle Obama's rallying cry, 'When they go low, we go high', was more effective in its use of the rhetorical antithesis of low and high (an antithesis as classic as the notion that higher is superior and down is inferior or base). Her particular strength was the almost casual constitution of the 'we', which creates a sense of community without denying the possibility of distinguishing a 'them' from 'us'. Frustratingly for her supporters, Hillary Clinton's concession speech after the failure of her campaign was one of her most humanly appealing, although even here formal rhetorical features stood out, such as her call 'to build that better, stronger, fairer America we seek'. The 'build' metaphor - often,

${ }^{68}$ Hillary Clinton’s ‘Super Tuesday’ election night speech (26 April 26 2016). 
as here, combined with 'strong' - is a staple of the political rhetorical project precisely because it promotes qualities of change and progress without sacrificing qualities of stability and security. The blatant tricolon 'better, stronger, fairer' advertises a rhetorical technique which might have been better left to work more subtly on the hearers' subconscious.

Wayne C. Booth writes that rhetoric's 'true home will be what we call "value disputes"', adding that 'in the political arena at its best, when a Pericles or a Lincoln or a Churchill reminds a nation of its deepest commitments; ... or in quarrels about the law or about constitutions...There is nothing "mere" about it'. ${ }^{69}$ The future Pericles, Lincoln, Churchill - or Michelle Obama - can still learn from the five canons of rhetoric that became the foundation of rhetorical education following the schemes of Aristotle, Cicero and Quintilian. I introduce my students to the five canons by representing them as a handful of rhetorical faculties - one each for the fingers and thumb of the rhetorician's right hand (in Rome, the left hand was weighed down by the toga so that the right hand became the active, eloquent gestural manus - with all the implications of handling and manipulation averred to earlier). I have rearranged the classical order of the five canons to produce an acronym, more properly an initialism, that is useful for reminding students of the essentials of rhetorical art: 'IAMDS'. Not very memorable in that form, but it indicates the phrase 'I AM DemoSthenes'. Demosthenes is reputed to have been the greatest orator of Ancient Greece. The initials IAMDS remind us of the basic elements of a persuasive presentation as the classical authors conceived them. 'I' stands for 'Invention', which includes the proof of one's case by reference to one's ethical sincerity (ethos), one's concern for the feelings of all involved (pathos) and - of course - one's logical reasoning (logos). 'A' stands for 'Arrangement', which reminds us that a persuasive presentation should be well planned; it should, for

${ }^{69}$ The Vocation of a Teacher (University of Chicago, Chicago 1988) 105, 110-11. 
example, have a clear beginning, middle and conclusion. The beginning is especially important. As Cicero wrote, 'a case is in real trouble if it does not seem to be gaining the upper hand with the very first words. Therefore...the strongest point in the speech should always come first, provided that... some of our excellent resources should also be reserved for the end' ${ }^{70}$ Shakespeare gives Mark Antony one of the most effective first lines of an exordium (the opening section, sometimes called the proemium) of an oration ever uttered: 'Friends, Romans, countrymen, lend me your ears' (3.2.74). As a class exercise with my students we examine this line in detail to appreciate why it works so well, and we each find and share (and perform with suitable movements, gestures etc) other opening lines of note. We do the same with the examples of effective concluding statements. Clarence Darrow's closing address to the jury in the murder trial of Henry Sweet, which is easily accessible online, is a class act and was a class favourite. The last section should be compulsory reading for all law students, it starts with the stirring sentiment of these lines: 'I do not believe in the law of hate. I may not be true to my ideals always, but I believe in the law of love, and I believe you can do nothing with hatred'. It ends with a rhyming couplet of sublime simplicity: 'I ask you, in the name of progress and of the human race, to return a verdict of not guilty in this case!'. Cicero did say that a speaker should reserve some of the best material for the end. Queen Elizabeth I exemplified the virtue of that technique in her famous speech to the troops at Tilbury Docks as they prepared to repel the Spanish armada. Where Shakespeare's Mark Antony opened his speech with the ascending tricolon 'Friends, Romans, countrymen', the Queen closed hers with the descending tricolon: 'enemies of my God, of my kingdom, and of my people'. ${ }^{71}$

\footnotetext{
${ }^{70}$ De Or. 2.313-314, quoted in The Art of Persuasion.

${ }^{71}$ The same descending tricolon had concluded the opening paragraph of the Queen's speech.
} 
I should probably learn my own lesson about rhetorical arrangement - I had almost forgotten that I am taking the reader through the meaning of IAMDS. 'M' stands for 'Memory'. It is always best to present without resorting to a written script. Cicero was a master of this and any stage actor knows that he or she is most plausible when performing without the physical pages of a script to prop them up. The student advocate will need to find their own best methods for remembering the essence and order of their best points - not least because the judge might require them to present the points in a different order to the one they had prepared. 'D' stands for delivery, which includes appropriate projection and clarity of voice, accuracy of pronunciation and vocabulary, and appropriate gesture. One of my students had a particularly strong accent and a hurried mode of speech. My advice to him was that there is nothing at all wrong with a strong accent if it does not get in the way of articulate delivery. Clarity is key, and slowing down assists greatly in achieving this. That said, one student who coughed in a moot mused in her post-moot reflections that this might have been to her advantage because it revealed her natural imperfections and evoked sympathy whilst simultaneously giving her an opportunity to demonstrate composure in the face of a disruption. ${ }^{72}$ Certainly there is no rhetorical outcome more impressive than to turn apparent weakness into a strength. As for vocabulary - the most important thing is to know what words mean before using them. If advocates use a word without understating its meaning, they can look foolish. More positively, research into the etymological origin of an apparently commonplace word might enable advocates to turn a word to their advantage. Likewise, one turn can make all the difference when it comes to gesture. In my feedback on one moot

\footnotetext{
${ }^{72}$ There little sympathy from the press when Prime Minister Theresa May's 2017 Conservative Party Conference speech was interrupted by a bout of coughing. The Guardian online featured the video under the heading 'great expectorations'.
} 
performance, I pointed out that the student had unconsciously raised his hand towards the judge in the classic 'stop' gesture. This doesn't look good from the judge's perspective. By turning his hand the other way round - palm down, instead of up - the advocate would have turned a dismissive gesture into a submissive one far more appropriate to the context of offering submissions to the judge. Last but not least, 'S' stands for 'Style'. A presentation should have a pleasing style. There should be rhythm and lyricism in the language used musicality even - and sentences should be constructed to be clear and elegant. The form should please as much as the substance, because strong substance can be spoiled by poor form. The phrase 'last but not least', which I used just now, would be an example of good style (it combines poetic assonance with the rhetorical trope of alliteration and an element of antithesis) were it not for the fact that it has become a cliché - and clichés seldom feature in a stylish presentation.

In order to deliver a speech one must actually have the physical power to do so, ${ }^{73}$ and to make the most of one's physical potential it is necessary to warm up with stretching and breathing exercises to whatever extent one is capable of doing so. Physical exercise and expressiveness doesn't come as naturally to law students in educational contexts as it does to, say, students of drama and dance. Despite this, members of the module group were happy enough to engage in some relatively low-key stretching (arm-raising, head rolling) exercises and vocal warm ups. Felix Nobis, a scholar and theatre professional who is a specialist in performed storytelling, stresses the need to 'tune voice and body to speak a story'. ${ }^{74}$ Quite

\footnotetext{
${ }^{73}$ Although we should be prepared to find power in untypical places. See, for example, the video article 'Cerebral palsy won't stop me becoming a lawyer' (BBC online 28 March 2018).

${ }^{74}$ Felix Nobis, 'Un-telling myself: performance (preparation) as research', in John Freeman
} 
apart from the psycho-physical benefits that come from joining word and deed, preparatory exercises carried out in a group context entail a degree of openness and humility that helps to foster a communal sense of shared endeavour. This is the essential business of an acting ensemble, but it is all too rare a thing in modern legal education. On that note, and it seems a good note to end on, it should be stressed that I positively encouraged the two members of each moot team to work together in preparing their arguments - and to work with their two moot opponents. The latter is not wholly unrealistic even in legal practice where some degree of disclosure to the other side is required by the rules of trial procedure. Any potential for student cooperation to spill over into improper plagiarism (however that might be defined) simply fails to materialise where students are assessed through the submission of a detailed and highly personal reflective journal and by a final moot performance. It is most doubtful that anybody would, or could, hand-write a credible diary of another person's experience of the module. As for the moot performance - each student stands or falls according to his or her own merits. The delight of group work is that the individual's merits are improved by working with their peers. One score years before the experiment of the module The Art of Advocacy, Peter Goodrich lamented that 'law school trains the soul, that it institutes the culture of law through a hierarchical conception of knowledge and through a variety of techniques of separation, isolation and fear'. He concluded that it 'need not be thus'. ${ }^{75}$ Indeed it need not. What law schools need now is to try something new, and to try something new in the case of advocacy will require the renaissance of something rather old.

(ed), Blood, Sweat \& Theory (Libri Publishing, Faringdon 2010) 185-194, 186.

${ }^{75}$ Peter Goodrich, 'Of Blackstone's Tower: Metaphors of Distance and Histories of the English Law School' in Peter Birks (ed), Pressing Problems in the Law Vol II: What are Law Schools For? (Oxford University Press, Oxford 1996) 59 at 68. 
